\title{
Neutrophil to lymphocyte ratio in diagnosis of complicated and non- complicated appendicitis
}

\author{
*Mervan Bekdas ${ }^{1}$, Hulya Ozturk ${ }^{1}$, Sevil Bilir Goksugur ${ }^{1}$, Fatih Demircioglu $^{1}$, Metin Tahaoglu ${ }^{1}$ \\ Sri Lanka Journal of Child Health, 2017; 46: 59-65
}

\begin{abstract}
Introduction: Acute appendicitis is one of the most common surgical problems of childhood. Late or misdiagnosis may increase the morbidity and mortality of this condition.
\end{abstract}

Objective: To test the utility of some laboratory methods, especially Neutrophil/Lymphocyte (N/L) ratio in rapid diagnosis of simple and complicated acute appendicitis

Method: The records of 498 cases hospitalized in paediatric surgery departments in Turkey between the years 2008 and 2014 with the suspicion or prediagnosis of acute appendicitis were retrospectively evaluated. Among these, 279 were diagnosed as non-complicated appendicitis while 73 were diagnosed as complicated appendicitis. The remaining 146 cases without the appendectomy requirement comprised the control group. Clinical, haematologic and radiologic data of all cases were investigated.

Results: Among the patients who had appendectomy, 214 (60.8\%) were male. The mean age of the patients was $9.8 \pm 3.5$ years. The mean C-reactive protein $(\mathrm{CRP})(46.6 \pm 54.1$ vs. $17.3 \pm 17.1$, $\mathrm{p}=0.048)$, white blood cell count (WBC) $(18.2 \pm 4.8$ vs. $10.3 \pm 4.6, \quad \mathrm{p}<0.001), \quad$ polymorphonuclear leucocyte $(14.5 \pm 4$ vs. $7.3 \pm 4.6, \mathrm{p}<0.001)$ and $\mathrm{N} / \mathrm{L}$ ( $8.4 \pm 6$ vs. $4.4 \pm 3.8, \mathrm{p}=0.024)$ values of the patients who had appendectomy were significantly higher. In diagnosis of acute appendicitis, the cut off value for $\mathrm{N} / \mathrm{L}$ was determined as $5(\mathrm{p}=0.003)$ (Sensitivity $72.7 \%$, specificity $67.8 \%$ ). Among complicated acute appendicitis cases, $\mathrm{N} / \mathrm{L}$ value was significantly higher $(10.9 \pm 7.2$ vs. $6.7 \pm 3.3, \mathrm{p}=0.04)$, and the number of patients with WBC greater than $12 \times 10^{3}$ and CRP value greater than $15 \mathrm{mg} / \mathrm{dl}$ were

${ }^{1}$ Department of Pediatrics, Abant Izzet Baysal University Faculty of Medicine, Bolu, Turkey

*Correspondence: vanbek@gmail.com

(Received on 16 May 2016: Accepted after revision on 17 June 2016)

The authors declare that there are no conflicts of interest

Personal funding was used in formulating the article.

Open Access Article published under the Creative

Commons Attribution CC-BY (c) significantly higher than the non-complicated group ( $65.8 \%$ vs. $34.3 \%, p=0.035$ and $67.1 \%$ vs. $32.9 \%$, $\mathrm{p}=0.046$, respectively). In diagnosis of complicated acute appendicitis, the cut off value for $\mathrm{N} / \mathrm{L}$ was determined as $7.2(\mathrm{p}=0.017)$ (Sensitivity $83.6 \%$, specificity $69.6 \%$ ).

Conclusions: In our study the most appropriate cut off value of $\mathrm{N} / \mathrm{L}$ in differentiating complicated acute appendicitis from non-complicated appendicitis was 7.2. In our study, $\mathrm{WBC}>12 \times 10^{3}$ and $\mathrm{CRP}>15 \mathrm{mg} / \mathrm{dl}$ values were important parameters distinguishing complicated appendicitis from non-complicated one.

DOI: http://dx.doi.org/10.4038/sljch.v46i1.8238

(Key words: Neutrophil to lymphocyte ratio, complicated appendicitis, non-complicated appendicitis, child)

\section{Introduction}

Abdominal pain is a common symptom of childhood. The important point that doctors should judge promptly in children admitted with this symptom is differentiation of acute appendicitis. Acute appendicitis is a common surgical problems in childhood ${ }^{1,2}$. Appendectomy is one of the most commonly performed operations with an incidence of about $10 \%$ lifelong ${ }^{3}$. In childhood, it is mostly reported in $2^{\text {nd }}$ decade $^{4}$. The reduction in fibres and increase in refined carbohydrates in diet is regarded as a risk factor for acute appendicitis ${ }^{5}$.

In appendicitis diagnosis, history and physical examination findings are important. Abdominal pain starting around umbilicus, nausea and anorexia are the classical admission symptoms. The most valuable finding in physical examination is tenderness of right lower quadrant. However, only $60 \%$ of acute appendicitis cases present with typical symptoms ${ }^{6}$. Especially symptoms in early periods may cause misdiagnosis of the clinical picture with other diseases ${ }^{7}$. Although with the history and physical examination the disease is commonly diagnosed, in some cases laboratory tests such as Creactive protein (CRP), erythrocyte sedimentation rate (ESR), white blood cell count $(\mathrm{WBC})^{8,9}$ and IL-6 ve IL- $10^{10}$ and imaging techniques such as ultrasonography or computed tomography ${ }^{11}$ may be required. With the increase in number of tests, the 
cost is also increasing. For this reason, more simple and trustworthy parameters like Neutrophil /Lymphocyte (N/L) ratio are necessary ${ }^{12}$.

The main reason for this high interest in the topic is the aim of decreasing morbidity and mortality of the disease. In early periods of the disease, with hurried diagnosis of the clinician, there are negative appendectomies and with late decision, perforations may take place ${ }^{6}$. These clinical pictures are generally reported in atypical cases that comprise $31.7 \%$ of acute appendicitis cases $^{13}$. In this study, our aim is to test the utility of some laboratory methods and especially N/L ratio in rapid diagnosis of simple and complicated acute appendicitis and by this way in reducing the diagnostic delays and negative appendectomy rates in childhood period.

\section{Method}

After the approval of local ethics committee, the study was started. The records of patients who were hospitalised in the paediatric surgery departments of Abant İzzet Baysal University Medical Faculty and Bolu Izzet Baysal Obstetrics and Paediatrics Hospital in Turkey between years 2008 and 2014 with the symptom of acute abdominal pain were retrospectively evaluated. Among these patients, those who were diagnosed with urinary system infection, respiratory tract infection, Familial Mediterranean Fever and acute gastroenteritis which may also cause the same symptoms were excluded. The patients included in the study were divided into 2 groups as patients with non-specific abdominal pain $(n=146)$ and patients operated for acute appendicitis $(n=352)$. The patients operated with conventional method with the diagnosis of acute appendicitis were also divided into 2 groups as non-complicated $(\mathrm{n}=279)$ or complicated $(\mathrm{n}=73)$ regarding the presence of phlegmon, abscess or perforation cases. The patients with non-specific abdominal pain were diagnosed with mesenteric lymphadenitis, ovarian cyst, peptic ulcer or cholelithiasis after the follow-up of 12-24 hours and performed tests. Patients with histologically proven negative appendectomy were not included in this study.

The clinical (location and duration of the abdominal pain, nausea, vomiting, fever, anorexia, diarrhoea, constipation, and dysuria) and laboratory data (haemoglobin, thrombocyte count, mean platelet volume (MPV), white blood cell (WBC), polymorphonuclear (PNL), lymphocyte count, CRP and abdominal ultrasonography) of included patients were investigated. The ultrasonographic evaluations of patients were performed by the radiologists of the medical centres. Regarding the complete blood counts, neutrophil/lymphocyte ratios were calculated. The data were analyzed with the Statistical Package for Social Sciences (SPSS, Inc., Chicago, IL) for Windows 15.0 statistical programme. The data were expressed as mean \pm standard deviation. In statistical evaluations, student-t, chi-square $\left(\chi^{2}\right)$ tests and ROC curve analyses were performed. The $p$ value of $<0.05$ was considered as statistically significant.

\section{Results}

Totally 567 patients, who were admitted to the paediatric emergency, and paediatric outpatient departments of 2 hospitals in Turkey and hospitalized with the pre-diagnosis of acute appendicitis in paediatric surgery departments in the study period were investigated; and 498 of those patients with the comprehensive data in their records were included in the study. Among those patients, $320(64.2 \%)$ were children while 178 $(35.7 \%)$ were adolescents. Conventional appendectomy was performed in $352(70.6 \%)$ of those patients with the diagnosis of acute appendicitis. Among the patients who had appendectomy, $214(60.8 \%)$ were male while 138 $(39.2 \%)$ were female. The mean age of the patients was $9.8 \pm 3.5$ years ( 7 months- 17 years). The features of patients with abdominal pain are summarized in Table-1.

In patients who had appendectomy, male gender $(p=0.038)$, nausea $(p=0.001)$, vomiting $(p=0.002)$, anorexia $(p<0.001)$ and constipation $(p<0.001)$ symptoms were significantly more common. In laboratory evaluation of patients who had appendectomy, CRP $(\mathrm{p}=0.048), \operatorname{WBC}(\mathrm{p}<0.001)$, PNL $(p<0.001)$ and $N / L(p=0.024)$ values were determined to be significantly higher.

The characteristics of patients with complicated and non-complicated acute appendicitis are shown in Table 2. 
Table-1: The characteristics of all patients admitted with abdominal pain

\begin{tabular}{|l|c|c|c|}
\hline \multicolumn{1}{|c|}{ Characteristic } & $\begin{array}{c}\text { Acute appendicitis } \\
(n=352)\end{array}$ & $\begin{array}{c}\text { Other causes of abdominal } \\
\text { pain }(n=146)\end{array}$ & p \\
\hline Age $($ years $)$ & $9.8 \pm 3.5$ & $10.2 \pm 3.1$ & 0.81 \\
\hline Gender $(\mathrm{n})$ & $214(60.8 \%)$ & $74(50.7 \%)$ & 0.038 \\
$\quad$ Male & $138(39.2 \%)$ & $72(49.3 \%)$ & 0.74 \\
Female & $196(55.6 \%)$ & $79(54.1 \%)$ & 0.45 \\
\hline Type of abdominal pain $(\mathrm{n})$ & $156(44.3 \%)$ & $67(45.9 \%)$ & 0.001 \\
$\quad$ Localized & $65.4 \pm 33.5$ & $69.2 \pm 21.2$ & 0.002 \\
\hline Generalized & $278(78.9 \%)$ & $95(65.1 \%)$ & $<0.001$ \\
\hline Time of abdominal pain $(\mathrm{hrs})$ & $252(71.5 \%)$ & $84(57.5 \%)$ & 0.006 \\
\hline Nausea $(\mathrm{n})$ & $326(92.6 \%)$ & $106(72.5 \%)$ & 0.51 \\
\hline Vomiting $(\mathrm{n})$ & $96(27.3 \%)$ & $58(39.7 \%)$ & $<0.001$ \\
\hline Anorexia $(\mathrm{n})$ & $11(03.1 \%)$ & $03(02.1 \%)$ & 0.077 \\
\hline Fever $(\mathrm{n})$ & $212(60.2 \%)$ & $63(43.2 \%)$ & 0.78 \\
\hline Diarrhoea $(\mathrm{n})$ & $24(06.8 \%)$ & $18(12.3 \%)$ & 0.57 \\
\hline Constipation $(\mathrm{n})$ & $13 \pm 1.5$ & $12.3 \pm 1.7$ & 0.092 \\
\hline Dysuria $(\mathrm{n})$ & $307 \pm 79$ & $293 \pm 80$ & 0.048 \\
\hline Haemoglobin $(\mathrm{g} / \mathrm{dl})$ & $7.9 \pm 0.8$ & $8.5 \pm 1.3$ & $<0.001$ \\
\hline Platelet count $(/ \mu \mathrm{l})$ & $46.6 \pm 54.1$ & $17.3 \pm 17.1$ & $<0.001$ \\
\hline MPV(fl) & $18.2 \pm 4.8$ & $10.3 \pm 4.6$ & 0.81 \\
\hline C-reactive protein $(\mathrm{mg} / \mathrm{dl})$ & $14.5 \pm 4$ & $7.3 \pm 4.6$ & 0.024 \\
\hline White cell count $\left(\mathrm{x} 10^{3} / \mu \mathrm{l}\right)$ & $2.1 \pm 0.8$ & $2.6 \pm 2.9$ & $4.4 \pm 3.8$ \\
\hline Neutrophil $\left(\mathrm{x} 10^{3} / \mu \mathrm{l}\right)$ & $8.4 \pm 6$ & & \\
\hline Lymphocyte $\left(\mathrm{x} 10^{3} / \mu \mathrm{l}\right)$ & & & \\
\hline N/L & & & \\
\hline
\end{tabular}

Table 2: The characteristics of patients with complicated and non-complicated acute appendicitis

\begin{tabular}{|c|c|c|c|}
\hline Characteristic & $\begin{array}{c}\text { Non-complicated } \\
\text { appendicitis }(n=279)\end{array}$ & $\begin{array}{l}\text { Complicated appendicitis } \\
(n=73)\end{array}$ & $\mathbf{p}$ \\
\hline Age (years) & $11 \pm 3.8$ & $11.8 \pm 4.2$ & 0.91 \\
\hline $\begin{array}{l}\text { Gender }(\mathrm{n}) \\
\text { Male } \\
\text { Female }\end{array}$ & $\begin{array}{l}173(62.1 \%) \\
106(37.9 \%)\end{array}$ & $\begin{array}{l}41(56.1 \%) \backslash \\
32(43.9 \%)\end{array}$ & 0.36 \\
\hline $\begin{array}{l}\text { Type of abdominal pain }(\mathrm{n}) \\
\text { Localized } \\
\text { Generalized }\end{array}$ & $\begin{array}{l}158(56.6 \%) \\
121(43.4 \%)\end{array}$ & $\begin{array}{l}51(69.9 \%) \\
22(30.1 \%)\end{array}$ & 0.04 \\
\hline Time of abdominal pain (hrs) & $61.8 \pm 28.2$ & $68.3 \pm 32.2$ & 0.24 \\
\hline Haemoglobin (g/dl) & $13.1 \pm 1.7$ & $12.8 \pm 1.1$ & 0.54 \\
\hline Platelet count $(/ \mu \mathrm{l})$ & $313 \pm 87$ & $297 \pm 66$ & 0.62 \\
\hline MPV(fl) & $8.1 \pm 1.1$ & $7.5 \pm 0.7$ & 0.13 \\
\hline $\begin{array}{l}\text { C-reactive protein }(\mathrm{mg} / \mathrm{dl}) \text { Overall } \\
<15 \mathrm{mg} / \mathrm{dl} \\
15 \mathrm{mg} / \mathrm{dl} \text { or }>\end{array}$ & $\begin{array}{c}39 \pm 27.1 \\
128(45.9 \%) \\
151(54.1 \%)\end{array}$ & $\begin{array}{l}50.5 \pm 64.3 \\
24(32.9 \%) \\
49(67.1 \%)\end{array}$ & $\begin{array}{l}0.59 \\
0.046\end{array}$ \\
\hline White cell count $\left(\mathrm{x} 10^{3} / \mu \mathrm{l}\right)$ & $17.6 \pm 4.5$ & $19.4 \pm 5.2$ & 0.34 \\
\hline $\begin{array}{l}\text { White cell count }(/ \mu \mathrm{l}) \\
<12 \times 10^{3} / \mu \mathrm{l} \\
12 \times 10^{3} / \mu 1 \text { or }>\end{array}$ & $\begin{array}{l}134(48 \%) \\
145(52 \%)\end{array}$ & $\begin{array}{l}25(34.2 \%) \\
48(65.8 \%)\end{array}$ & 0.046 \\
\hline Neutrophil $\left(\times 10^{3} / \mu 1\right)$ & $14.2 \pm 4.2$ & $15.3 \pm 3.1$ & 0.49 \\
\hline Lymphocyte (x10 3 1) & $2.3 \pm 0.8$ & $1.7 \pm 0.6$ & 0.052 \\
\hline $\mathrm{N} / \mathrm{L}$ & $6.7 \pm 3.3$ & $10.9 \pm 7.2$ & 0.04 \\
\hline
\end{tabular}

In diagnosis of acute appendicitis, the cut off value for $\mathrm{N} / \mathrm{L}$ was determined as $5(\mathrm{p}=0.003)(95 \%$ CI (0.6-0.94)). For that cut off value sensitivity was $72.7 \%$, and specificity was $67.8 \%$. Seventy three $(20.7 \%)$ of the appendectomy performed cases were diagnosed with complicated acute appendicitis. Among those cases, 41 (56.1\%) were male while 32 $(43.8 \%)$ were female. The mean age of the patients was $11.5 \pm 3.5$ years. Localized abdominal pain was significantly more common in complicated acute 
appendicitis cases $(69.9 \%$ vs. $30.1 \%, p=0.04)$. In those cases, N/L ratio was significantly higher (10.9 \pm 7.2 vs. $6.7 \pm 3.3, \mathrm{p}=0.04)$. When compared with the simple appendicitis group there was not a significant difference in complicated appendicitis group regarding CRP values; but in complicated group the number of patients with CRP value greater than $15 \mathrm{mg} / \mathrm{dl}$ were significantly higher than the non-complicated group. When compared with the simple appendicitis group there was no significant difference in the complicated appendicitis group regarding $\mathrm{WBC}$ and CRP values; but in complicated group the number of patients with WBC greater than $12 \times 10^{3} / \mu \mathrm{L}$ and CRP value greater than $15 \mathrm{mg} / \mathrm{dl}$ were significantly higher than the non-complicated group $(65.8 \%$ vs. $34.3 \%, p=0.035$ and $67.1 \%$ vs. $32.9 \%, p=0.046$, respectively). In diagnosis of complicated acute appendicitis, the cut off value for $\mathrm{N} / \mathrm{L}$ was determined as $7.2(p=0.017)(95 \%$ CI $(0.6-0.94))$. For that cut off value sensitivity was $83.6 \%$, and specificity was $69.6 \%$.

\section{Discussion}

To decrease the morbidity and mortality rates caused by acute appendicitis; its prompt and definite diagnosis is warranted. Performance of some different hematological and radiological tests is not enough every time for the exact diagnosis in children. For those cases, simple parameters are required for prompt and correct diagnosis ${ }^{13}$. As in our study, acute appendicitis is more common in males ${ }^{4,14}$. The exact cause of this is still not defined. However, there are some studies more commonly reporting acute appendicitis in females ${ }^{15}$.

The diagnosis of acute appendicitis in childhood is mainly suspected by doctors with the admission symptoms. Together with the abdominal pain; nausea-vomiting and anorexia are the most commonly determined admission symptoms ${ }^{16}$. In our study, along with those symptoms, constipation was also determined as significantly higher. In complete blood count, a simple test, WBC, absolute neutrophil count and $\mathrm{N} / \mathrm{L}$ ratio can be obtained and these parameters were investigated in many other studies as inflammatory determinants ${ }^{8,9}$. Low cost is the main advantage of these parameters. With the augmented inflammation, increase in those parameters is another advantage. On the other hand, there are also studies reporting low sensitivity and specificity rates of especially WBC and absolute neutrophil count in inflammatory conditions ${ }^{17}$. In our study, we have determined significantly increased CRP, WBC and $\mathrm{N} / \mathrm{L}$ ratio in acute appendicitis cases compared with the cases admitted with non-specific abdominal pain. Dueholm et $a 1^{18}$ defined that normal WBC, N/L and CRP values excludes the diagnosis of acute appendicitis while Gronroos ${ }^{19}$ suggested just the opposite.

In $10-20 \%$ of people, appendix may be located atypically $^{20,21}$. Despite the evolutions in diagnostic methods in recent years, the perforation rate of $19 \%$ and mis-diagnosis rate of $10 \%$ in acute appendicitis in children still could not be improved ${ }^{22}$. Especially keeping atypical cases may increase the perforation possibility while operating them may cause the negative appendectomies. On the other hand, Saraç et $\mathrm{al}^{23}$ defined the most common cause of perforated appendicitis as not distinguishing the clinical picture by the doctors. Especially in children younger than 5 years of age, the causes of perforation were determined as barely expression of children themselves, and difficulty in performance of physical examination ${ }^{24}$. In that aspect, N/L ratio seems to solve these problems. In diagnosis of acute appendicitis, N/L by itself is a better parameter than CRP, WBC and absolute neutrophil count ${ }^{25}$ but different cut-off values were determined in previous studies. In our study, the best cut-off value of $\mathrm{N} / \mathrm{L}$ that can differentiate the inflamed appendix from the normal one was determined as 5 (75.2\% sensitivity and $67.8 \%$ specificity). This obtained value was between the values of 3.5 reported by Yazic1 et $\mathrm{al}^{12}$ and Białas et $\mathrm{al}^{26}$ and 6 reported by Markar et $\mathrm{al}^{25}$.

Complicated acute appendicitis pictures due to phlegmon, abscess or perforation are still important. Generally these situations take place due to the delay in interventions with a rate ranging between $21.5 \%{ }^{27}$ and $28 \%{ }^{28}$. In our study, we have determined that localized abdominal pain in right lower quadrant was significantly more common in this condition. In those conditions with more severe inflammation, higher CRP and neutrophil counts were determined ${ }^{29}$. Nevertheless, N/L ratio is more valuable in diagnosis of complicated acute appendicitis compared with $\mathrm{WBC},{ }^{26}$ and moreover it may reach higher values compared with the noncomplicated appendicitis ${ }^{25,29,30}$.

In our study, the most appropriate cut off value of $\mathrm{N} / \mathrm{L}$ in differentiating complicated acute appendicitis from non-complicated one was determined as $7.2(83.6 \%$ sensitivity, $69.6 \%$ specificity). This obtained value was between the values of 5.7 reported by Kahramanca et $\mathrm{al}^{13}$ and 8 reported by Ishizuka et $\mathrm{al}^{29}$. In early periods of acute appendicitis, due to the consumption of PNL in marginal pool, PNL increases more than WBC which is the reason of increase in N/L ratio in early periods. In complicated appendicitis, PNL production intensifies while lymphocyte count decreases in bone marrow and this alteration is an 
important cause of increase in $\mathrm{N} / \mathrm{L}$ ratio in complicated appendicitis ${ }^{31-33}$.

In clinical pictures other than acute appendicitis, admitting with similar symptoms; WBC rarely exceeds $12 \times 10^{3} / \mathrm{mm}^{3,26}$. Erturk et al ${ }^{16}$ reported that, in childhood acute appendicitis cases, total leucocyte count higher than $11.8 \times 10^{3} / \mu \mathrm{L}$ and CRP values higher than $13.5 \mathrm{mg} / \mathrm{dl}$ have high sensitivities. In our study, we have determined that WBC $>12 \times 10^{3}$ and $\mathrm{CRP}>15 \mathrm{mg} / \mathrm{dl}$ values were important parameters distinguishing complicated appendicitis from non-complicated one.

\section{Conclusions}

- In our study the most appropriate cut off value of $\mathrm{N} / \mathrm{L}$ in differentiating complicated acute appendicitis from non-complicated appendicitis was 7.2.

- In our study, $\mathrm{WBC}>12 \times 10^{3}$ and $\mathrm{CRP}>15$ $\mathrm{mg} / \mathrm{dl}$ values were important parameters distinguishing complicated appendicitis from non-complicated one.

\section{References}

1. Shera AH, Nizami FA, Malik AA, Naikoo ZA, Wani MA. Clinical scoring system for diagnosis of acute appendicitis in children. Indian Journal of Pediatrics 2011; 78:28790.

https://doi.org/10.1007/s12098-010-02859

PMid: 21046287

2. Goldman RD, Carter S, Stephens D, Antoon R, Mounstephen W, Langer JC. Prospective validation of the pediatric appendicitis score. Journal of Pediatrics 2008; 153:278-82.

https://doi.org/10.1016/j.jpeds.2008.01.03 3

PMid: 18534219

3. Benjamin IS, Patel AG. Managing acute appendicitis. British Medical Journal 2002; 325(7363):505-6.

https://doi.org/10.1136/bmj.325.7363.505

4. Humes DJ, Simpson J; Acute appendicitis. British Medical Journal 2006; 333(7567):530-4.

https://doi.org/10.1136/bmj.38940.664363. $\mathrm{AE}$

PMid: 16960208 PMCid: PMC1562475

5. Caffarelli C, Santamaria F, Cesari S, Di Giorgio A, Bernasconi S. Progress in pediatrics in 2011. Choices in endocrinology, gastroenterology, hematooncology, infectious diseases, otolaryngology, pharmacotherapy and respiratory tract illnesses. Italian Journal of Pediatrics 2012; 38:23-7.

https://doi.org/10.1186/1824-7288-38-23

PMid: 22682313 PMCid: PMC3431994

6. Ma KW, Chia NH, Yeung HW, Cheung MT. If not appendicitis, then what else can it be? A retrospective review of 1492 appendectomies. Hong Kong Medical Journal 2010; 16(1):12-7.

PMid: 20124568

7. Bundy DG, Byerley JS, Liles EA, Perrin EM, Katznelson J, Rice HE: Does this child have appendicitis? Journal of the American Medical Association 2007; 298:438-51.

https://doi.org/10.1001/jama.298.4.438

PMid: 17652298 PMCid: PMC2703737

8. Yang HR, Wang YC, Chung PK, et al. Role of leukocyte count, neutrophil percentage, and C-reactive protein in the diagnosis of acute appendicitis in the elderly. American Surgeon 2005;71:344-7. PMid: 15943411

9. McGowan DR, Sims HM, Zia K, et al. The value of biochemical markers in predicting a perforation in acute appendicitis. Australia and New Zealand Journal of Surgery 2013; 83:79-83.

https://doi.org/10.1111/ans. 12032

PMid: 23231057

10. Yildırım O, Solak C, Koçer B, Unal B, Karabeyoglu M, Bozkurt B, et al. The role of serum inflammatory markers in acute appendicitis and their success in preventing negative laparotomy. Journal of Investigative Surgery 2006;19(6):34552.

https://doi.org/10.1080/089419306009856 86

PMid: 17101603

11. Behzatoğlu B, Hatipoğlu E, Bayramoğlu S, ve ark. Comparison of ultrasonographic and computed tomographic findings in the diagnosis of acute apendiciti. Bakırköy Tip Dergisi 2006; 2:22-4.

12. Yazıcı M, Ozkisacik S, Oztan MO, Gürsoy H. Neutrophil/lymphocyte ratio in the diagnosis of childhood appendicitis. 
Turkish Journal of Pediatrics 2010; 52(4):400-3.

PMid: 21043386

13. Kahramanca S, Ozgehan G, Seker D, et al. Neutrophil-to-lymphocyte ratio as a predictor of acute appendicitis. Ulus Travma Acil Cerr Derg 2014; 20(1):19-22. https://doi.org/10.5505/tjtes.2014.20688 PMid: 24639310

14. Tsioplis C, Brockschmidt C, Sander S, et al. Factors influencing the course of acute appendicitis in adults and children. Langenbeck's Archives of Surgery 2013; 398:857-67.

https://doi.org/10.1007/s00423-013-1096-z PMid: 23832465

15. Shrestha R, Ranabhat SR, Tiwari M. Histopathologic analysis of appendectomy specimens. Journal of Pathology of Nepal 2012; 2(3):215-9. https://doi.org/10.3126/jpn.v2i3.6025

16. Erturk A, Tuncer IS, Balcı O, et al. The Value of Pediatric Appendicitis Score and Laboratory Findings on the Diagnosis of Pediatric Appendicitis. Turkish Journal of Pediatric Disease 2015;2:79-84.

17. Coleman C, Thompson JE Jr, Bennion RS, Schmit PJ. White blood cell count is a poor predictor of severity of disease in the diagnosis of appendicitis. American Surgeon 1998; 64: 983-5.

PMid: 9764707

18. Dueholm S, Bagi P, Bud M: Labaratory aid in the diagnosis of acute appendicitis: a blinded, prospective, trial concerning diagnostic value of leukocyte count, neutrophil differential count Creactive protein. Diseases of the Colon and Rectum 1989; 32:855-9.

https://doi.org/10.1007/BF02554555

19. Grönroos JM. Do normal leucocyte count and Creactive protein value exclude acute appendicitis in children? Acta Paediatrica 2001; 90:649-51.

https://doi.org/10.1080/08035250117900

PMid: 11440098

20. Consorti ET et al; Diagnosis and Treatment of Caecal Volvulus, Postgraduate Medical Journal 2005;81:772-6. https://doi.org/10.1136/pgmj.2005.035311 PMid: 16344301 PMCid: PMC1743408

21. McKay R, Shepherd J; The use of the clinical scoring system by Alvarado in the decision to perform. Americal Journal of Emergency Medicine 2007; 25(5):489-93. https://doi.org/10.1016/j.ajem.2006.08.020 PMid: 17543650

22. Lee SL, Ho HS. Acute appendicitis: is there a difference between children and adults? American Surgeon 2006; 72(5):409-13.

PMid:16719195

23. Saraç M, Bakal U, Tartar $\mathrm{T}$ et al. Apandisitlerin Perfore Olmasında Hekimlerin Rolü. Fırat Medical Journal 2014; 19(3): 126-9.

24. Yildız T, Bozdag Z, Erkorkmaz U, et al. Çocuk apandisitlerinde risk faktörlerinin analizi. Ulus Travma Acil Cerr Derg 2013; 19(6):554-8.

https://doi.org/10.5505/tjtes.2013.52059

PMid: 24347216

25. Markar SR, Karthikesalingam A, Falzon A, Kan Y. The diagnostic value of neutrophil: lymphocyte ratio in adults with suspected acute appendicitis. Acta Chir Belg 2010; 110(5):543-7.

PMid: 21158332

26. Białas M, Taran K, Gryszkiewicz M, Modzelewski B. Evaluation of neutrophillymphocyte ratio usefulness in the diagnosis of appendicitis. Wiad Lek 2006; 59(9-10):601-6.

PMid: 17338113

27. Singh M, Kadian YS, Rattan KN, et al. Complicated appendicitis: Analysis of risk factors in children. African Journal of Pediatric Surgery 2014; 11(2):109-13. https://doi.org/10.4103/0189-6725.132796 PMid: 24841008

28. Mohajerzadeh L, Rouzrokh M, Tabari AK, et al. Laparoscopic Appendectomy in Complicated Appendicitis of Children. Annals of Colorectal Research 2014; 2(1):e16599.

https://doi.org/10.17795/acr-16599

29. Ishizuka M, Shimizu $T$, Kubot $K$. Neutrophil-to-Lymphocyte Ratio Has a Close Association With Gangrenous 
Appendicitis in Patients Undergoing Appendectomy. International Surgery 2012; 97:299-304.

https://doi.org/10.9738/CC161.1

PMid: 23294069 PMCid: PMC3727267

30. Keskek M, Tez M, Yoldas O, Acar A, Akgul O, Gocmen E et al. Receiver operating characteristic analysis of leukocyte counts in operations for suspected appendicitis. Americal Journal of Emergency Medicine 2008; 26:769-72. https://doi.org/10.1016/j.ajem.2007.10.036 PMid: 18774040

31. Abraham E, Wunderink R, Silverman H, et al. Efficacy and safety of monoclonal antibody to human tumor necrosis factor alpha in patients with sepsis syndrome. A randomized, controlled, double-blind, multicenter clinical trial. TNF-alpha MAb Sepsis Study Group. Journal of the American Medical Association 1995; 273: 934-41.

https://doi.org/10.1001/jama.273.12.934

PMid: 7884952
32. Dinarello CA, Gelfand JA, Wolff SM Anticytokine strategies in the treatment of the systemic inflammatory response syndrome. Journal of the American Medical Association 1993; 269: 1829-35. https://doi.org/10.1001/jama.269.14.1829 PMid: 8459516

33. Fisher CJ Jr, Dhainaut JF, Opal SM, et al. Recombinant human interleukin 1 receptor antagonist in the treatment of patients with sepsis syndrome. Results from a randomized, double-blind, placebocontrolled trial. Phase III rhIL-1ra Sepsis Syndrome Study Group. Journal of the American Medical Association 1994; 271: 1836-43.

https://doi.org/10.1001/jama.1994.035104 70040032

PMid: 8196140 